\title{
A MORPHOLOGICAL ANALYSIS OF DERIVATIONAL BOUND MORPHEME IN MAGENA LANGUAGE: A LANGUAGE SPOKEN IN CENTRAL SUMBA REGENCY
}

\author{
A.Y.A. Kay ${ }^{1}$, N.L.P.S. Adnyani ${ }^{2}$ \\ ${ }^{123}$ English Language Education, Universitas Pendidikan Ganesha, Singaraja \\ e-mail: arapinyaku@gmail.com , niluhputusriadnyani@gmail.com
}

The aim of the study is to identify the morphological of derivational bound morpheme in Magena Language and to find out the functions of Morphological of derivational bound morpheme in Magena Language." The writer uses the descriptive qualitative method which is aimed to describe bound Morphemes in Magena Language. The subject of this writing is five informants of Magena in collecting the data. The writer assigned the informants to do the storytelling and record them. After that the data were analyzed using the descriptive qualitative method. The findings reveal that the derivational bound morphemes that appear are free morphemes, which consists of a noun, verb. adverb, adjectives. It was also found that the function of the suffix -ne was as possessive of the first-person singular, the function of the suffix - ne as possessive of first - singular, the function of the suffix -me as possessive of first-person plural, The function of the suffix -ya refers to third-person singular as an adverb. Circumfixes pa - and - gi have the function to change the part of speech. From the result gained the writer could say that derivational bound morpheme in Magena language has their own character and their own function in use.

\section{Keywords: A Morphological; Derivational Bound Morpheme}

\section{INTRODUCTION}

Sumba Island was divided into two regencies: East Sumba Regency and its capital city is Waingapu and West of Sumba Regency and its capital city is Waikabubak. In 2007, West Sumba regency was divided into three regencies: central of Sumba Regency and its capital city is Waibakul, West of Sumba Regency and its capital is Waikabubak, and South West of Sumba Regency and its capital city is Tambolaka (Kosi et al, 2010:3). In 2008, Central Sumba Regency was divided into 5 subdistricts: Umbu Ratunggay, west Umbu Ratunggay,Katiku Tana, south Katiku Tana and Mamboro) and 43 villages. Umbu Ratu Nggay and west Umbu Ratunggay subdistrict have the largest number of villages (11 villages), while the least number of villages was district Katiku Tana, those are; Anakalang, Makata Keri, Umbu Riri, Mata Woga, and Kabela Wuntu. (BPS-Statistics of sumba Barat regency, 2009:23). There are Four languages used by the society of central Sumba Regency. Those are Maggara language (language used by people in katiku Tana, south Katiku Tana, partly of West umbu Ratunggay subdistrict), Magena language (language used by partly people in west Umbu Ratunggay and Umbu Ratunggay subdistrict). Mapaina language (language used by Pondok people at west Umbu Ratunggay subdistrict) and Mapani language (language used by people of Mamboro. (Sabaora, 2009:19)

The writer focuses her research on one of the above Magena languages, which is used partly by the people in west Umbu Ratunggay and umbu Ratunggay sub- district. Magena belongs to the district and located in south central of sumba. In Magena language of Magena it is found a lot of derivational Bound Morpheme of words. Bound morpheme like -ify and action are called Derivational morphemes. In the addition of -ify to pure - means "to making pure" the form that result from the addition of derivational morpheme is called a derived word. (Fromklin (2005:48) The writer discusses about derivational of bound morphemes in Magena language of central Sumba because the background of the writer is from Sumbanese and speaks. Magena language in this case belongs to the Austronesia and Polynesian language. The morphological analysis typically consists of the identification parts of words, or more technically, constituents of words. Morphological analysis primary consists in breaking up 
words into their part and establishing the rules that govern the occurrence of these parts. The smallest meaningful constituent of words and the stem nut represent a morpheme. instantiation of a primarily systematic approach to morphology is morpheme-based morphology. In this study focus to analyze of the words into their constituent in morphemes.

Morphemes in the morphological science is conceived of as the syntax of morphemes, as the set of principles for combining morphemes into word morphemes, the morphological building blocks of words, are divined as the minimal linguistic units with a lexical or a grammatical meaning. (Geert Booij (2007:23) In language the rules formation or the changing process of words called Morpheme. So morpheme is very important. As part of the language system, the function of Morphology is to identify the small units in language is morpheme itself. Derivational Morphemes is added to a base, it adds meaning. The derived word may also be of different grammatical class than the original word, as shown by suffixes such as -able and -ly. When a verb is suffixed with -able, the result is an adjective, as in desire +able. (Fromklin (2005:48). According to Gay (1992:73) in Ngongo (2013:16), Morphology and Morphological Process is the study of the internal structure of words (Haspelmath,2002:1). In another resource, the definition of morphology was made clear, that is, the internal structure of the grammatical of words, in which morpheme as the basic elements or the smallest unit in its scope of study. Another definition of morphology was that I is a branch of linguistics which studies the structure of words grammatically. Our morphological knowledge has two components: knowledge of the individual morphemes and knowledge of the rules that combine them.

Morphologically complex words consist of a morpheme root and one or more affixes. Some examples of English roots are paint in painter, read in reread, ceive in conceive, and ling in linguist. A root may or may not stand alone as a word (paint and read do; ceive and ling don't). 7 One of the things we know about particular morphemes is whether they can stand alone or whether they must be attached to a base morpheme. Some morphemes like boy, desire, gentle, and man may constitute words by themselves. These are free morphemes. Other morphemes like -ish, -ness, -ly, pre-, trans-, and un- are never words by themselves but are always parts of words. These affixes are bound morphemes. We know whether each affix precedes or follows other morphemes. Thus, un-, pre- (premeditate, prejudge), and bi- (bipolar, bisexual) are prefixes. They occur before other morphemes. Some morphemes occur only as suffixes, following other morphemes. English examples of suffix morphemes are -ing (sleeping, eating, running, climbing), Morphological knowledge has two components; knowledge of the individual morphemes and knowledge of the rules that combine them. One of the things we know about particular morpheme is whether they can stand alone or whether they must be attached to a host morpheme. Some morpheme such as boy, desire, gentle and man may constitute words by themselves.

Fromklin (2005:43) suggests a clear instantiation of a primarily systematic approach to morphology is morpheme-based morphology. In this approach, focus is on the analysis of words into their constituent morphemes. That is, morphology is conceived of as the syntax of morphemes, as the set of principles for combining morphemes into words. Morphemes, the morphological building blocks of words, are defined as the minimal linguistic units 8 with a lexical or a grammatical meaning. For instance, the noun buyer consists of two morphemes, buy and -er. The verbal morpheme buy is called a free or lexical morpheme, because it can occur as a word by itself, whereas -er is an affix (hence a bound morpheme that cannot function as a word on its own). This is indicated by the hyphen preceding this morpheme: it requires another morpheme to appear before it in a word. Each of these morphemes is listed in the morpheme list of English: eat as a morpheme of the category Verb (V), and -er as an affixal morpheme of the category Noun $(\mathrm{N})$ that is specified as occurring after verbs: [ $\mathrm{V}-]$. This specification of the affix -er assigns it to the subcategory of affixes that combine with verbs, and hence we call it a sub categorization property of this affix. (Geert Booij $(2007: 24)$ 2.2 Definition of Morphemes Morpheme is the traditional term for the most elemental unit of grammatical form. Morpheme is the derived from the Greek work "morph" that meaning form Fromklin (2005:41) we can also said the morpheme is the minimal units of meaning or the small part of the language we can also said that morpheme is the grammatical unit in which there is a arbitrary union of a sound and meaning that cannot be further analyzed. The 
morpheme concatenation approach and the lexeme-based rule approach may in fact lead to similar analyses of word structure. In both approaches, the poly morphemic noun swimmer will have the internal structure [[swim]V er]N. 9 The (minor) difference is that in the rule approach, the bound morpheme -er has no lexical category label of its own, since it is not a lexical entry. Yet, we should realize that the rule interpretation of an extendable word pattern, has a paradigmatic flavour: it is not a rule about morpheme concatenation, but it specifies a formal and semantic operation (affix attachment and change of meaning) on lexemes. Part of knowing language is knowing its morphology Words have internal structure, which is rulegoverned. Uneaten, unadmired, and ungrammatical are words in English, but *eatenun, *admiredun, and grammaticalun (to mean "not eaten," "not admired," "not grammatical") are not, because we form a negative meaning of a word not by suffixing un- but by prefixing it. When Samuel Goldwyn, the pioneer moviemaker, announced, "In two words: im-possible," he was reflecting the common view that words are the basic meaningful elements of a language. We have seen that this cannot be so, because some words contain several distinct units of meaning. The linguistic term for the most elemental unit of grammatical form is morpheme. The word is derived from the Greek word morphe, meaning "form." If Goldwyn had taken a linguistics course, he would have said, more correctly, "In two morphemes: impossible."The study of the internal structure of words, and of the rules by which words are formed, is morphology. This word itself consists of two morphemes, morph + ology. The suffix -ology means "science of" or "branch of knowledge concerning." Thus, the meaning of morphology is "the science of (word) 10 forms." Morphology is part of our grammatical knowledge of a language. Like most linguistic knowledge, this is generally unconscious knowledge. A single word may be composed of one or more morphemes Like most linguistic knowledge, this generally unconscious knowledge. A single word may be composed of one or more morpheme. (Fromklin, 2005 :41) Example : One morpheme : Boy, desire Two morpheme : Boy+ ish : Desire + able There morpheme : Boy + ish + ness : Desire +Able + ity Four morpheme : un + desire + able +ity More that morpheme : un + gentle + man + li + ness. 2.3 Derivational bound morphemes Derivational morpheme have are clear semantic content. In this sense they are like content words as we have seen, when derivational Morphemes is added to a root or stem, it adds meaning. the bound morpheme -er has no lexical category label of its own, since it is not a lexical entry. The derived word may also be of different grammatical class than the original word, as shown by suffixes such as -able and -ly. When a verb is suffixed with -able, the result is an adjective, as in desire + able derivational morphemes. When they are added to a base, a new word with a new meaning is derived. The addition of -ify to pure-purify-means "to make pure," and 11 the addition of cation-purification-means "the process of making pure." If we invent an adjective, pouzy, to describe the effect of static electricity on hair, you will immediately understand the sentences "Walking on that carpet really pouzified my hair" and "The best method of pouzification is to rub a balloon on your head." This means that we must have a list of the derivational morphemes in our mental dictionaries as well as the rules that determine how they are added to a root or stem. The form that results from the addition of a derivational morpheme is called a derived word (Fromklin 2005: 49). kinds of morphemes morphemes consist of two kinds they are. (Whitman in Jacob, $2006: 41$ ). 2.2.1. Free morpheme Free morpheme is morpheme than can stand alone and constitute words by themselves. (Jacob, 2006: 42). example: girl, boy, love, eat, and drink. 2.2.2. Bound morpheme Bound morpheme is a morpheme that can not stand alone and never word but always part of words. never exist as word themselves but are always attached to some others morphemes. (Jacob, $2006: 42$ ). example : -un, -re, -dis, -ly, -ed, ist, -en. Each bound morpheme can attached to the free morpheme based on the function for example bound morpheme re is bound morpheme that attached only to verbs and attached only to the beginning of the verbs not the end of the verbs. ( Jacob, $2006: 42$ ) example : re + start $=$ restart $r e+$ mind $=$ remind 14 2.2.2.1. Affixes affixes are related to as bound morpheme because they can not occur "un attached" affixes consists of prefix and suffix (Jacob, 2006 43: ). 2.2.2.1.1. Prefix prefix is word that only occur before other morpheme or prefix is attached to the beginning of a word. prefix is syllable, it is placed in front of a word to change its meaning. (Jacob, 2006: 43) example : 1. (un-) un + believe $+($-able $)=$ unbelieveable 2. (ir-) ir + place $+($-able $)=$ irreplaceable 3 . (dis-) dis + 
play $=$ display 4. $($ re-) re + star $+(-$ ing $)=$ restarting. 2.2.2.1.2. Suffix suffix is a syllable, place after a word to that occur only after other morpheme that occur only after other morpheme. (Jacob,43 : 2006). example : 1 . friend + -ly $=$ friendly 2 . clever + -est $=$ cleverest 3 . play + -ed $=$ played 4. happy + -ness $=$ happiness 5 . eat +-en = eaten 6 . use + -less $=$ useless 15 2.2.2.2. Circumfixes there are also language which have circumfixes is morphemes which are attach to a root or stem morpheme both initially and finally, or circumfixes is morphemes which are attach to a root or stem both prefix and suffix. example : 1. (un-) + believe (-able) 2. (re-) + start (-ing) 3. (un-) + desire (-able) 4. (mis-) +under (-ing) 5. (un-) + forget (-able) 6. (un-) + beat (-en) 7. (un-) + deliver (-ed) 8. (un-) + publish (-ed) 9.(un-) + list (-ed) 10.(un-) + dedy (able) 11. (un-) + take (-en) 12. (re-) + play (-ing) 2.2.3. Derivational morpheme When some morpheme attach to words they create or derive new words either by changing its part of speech. ( Jacob, 2006 : 45). 16 for example : un in unhappy creates a new word that have an opposite meaning of happy use in word useless create a new word that have an opposite meaning of use. Based on the example give we could say that derivational morpheme is morpheme that can change the meaning of part of speech of a word that they attached. Example : re- + start (verb) = restart (noun) Quick + ness (adjective) = quickness (noun) a. Derivational morphemes change the part of speech the meaning of a word. example : judge +- ment $=$ judgement re + -active $=$ reactive $b$. Derivational morpheme are not required by syntax, they typically indicate semantic relation outside the word. example : - un + kind, word un related to not or not kind -un + believe, word un is also relate to no or not believe $17 \mathrm{c}$. Derivational morpheme are usually not very productive, derivational morphemes generally are selective about that they will combine. For example: suffix hood occur with just a new nouns such as: brother (brotherhood), neighbor (neighborhood) knight (knighthood) d. derivational morpheme may be prefix or suffix example : 1. pre- arrage = prearrange 2 . arrage - men $=$ arrangement 3.dis - play $=$ display 4.re - play $=$ replay 5 . love -less =loveless 2.2.4. Inflectional morpheme is the morpheme that serve a purely grammatical function, never creating a new word but only a different form of the same word. (Jacob, $2006: 73$ ). inflectional morphemes are all suffixes. There are only eight inflectional morphemes in English. some characteristics of each are listed below to help and make the distinction clearer (Fromklin 2005: 73). a. inflectional morpheme do not change the meaning of part of speech. For example: 1. Big - bigger- biggest ( are all adjective) 2. tall,-taller,-tallest (are all adjective) 3. Small - smaller - smallest (are all adjective) 4. clever,-cleverer,-cleverest (are all adjective) b. inflectional morpheme are required by the syntax, they typically indicate syntactic or semantic relation between different words in a sentence. example : he eats banana every day (word $s$ mark the third person). 19 c. inflectional morpheme are very productive they typically occur with all members of same large class of morphemes example : cats, dogs, apples, boxes, mans. d. inflectional morpheme occur at the margin of a word after only derivational morphemes. example : ration $-\mathrm{al}-\mathrm{iz}-\mathrm{ation}-\mathrm{I}(-\mathrm{s}$ is inflectional and appears at the end of the verbs) e. are suffixes only example : -dis + play = display -re +start = restart -un +kind = unkind 2.5 Function morphological of derivational bound morphemes Grammatical morphemes or function words constitute a closed class; that is new function words do not enter the language.

Function words and bound morphemes are inserted into sentences according to the syntactic structure (Fromklin, 2005: 107). The past tense morpheme, often written as -ed, is added as a suffix to a verb, and the future tense morpheme will, is inserted in a sentence according to the syntactic rules of English. Though it may be true that most, if not all, languages the categories noun and verb (and possibly a few others), it is also clear that other categories are found in some languages but not others (Akmajian, 2001: 21-22). while function morphemes have more of a 20 grammatical role. For example, the morphemes fast and sad can be considered content morphemes. On the other hand, the suffix -ed belongs function morphemes given that it has the grammatical function of indicating past tense. Although these categories seem very clear and intuitive, the idea behind it can be harder to grasp given that they overlap with each other. In the other type of word-formation, derivation, exemplified by the word swimmer, use is made of morphological operations on lexemes, whereas in compounding, two or more lexemes are combined into a new word (Geert Booij (2007: 29). The examples of an ambiguous situation are the preposition over and the 
determiner your, which seem to have a concrete meaning, but are considered function morphemes because their role is to connect ideas grammatically. A general rule to follow to determine the category of a morpheme is: a. Function morphemes can be free morphemes that are prepositions, pronouns, determiners, and conjunctions. Additionally, they can be bound morphemes that are inflectional affixes. b. Contrary to these function words, i.e. free grammatical forms like is (walking), to, and, are systematic, c. Their meaning is partly or exclusively dependent on their context $d$. Affixes occur either as prefixes or suffixes. They are always bound and can be lexical (derivational) as all e. prefixes: un- in unhappy, or grammatical as all inflectional endings, suffixes such as -ed in worked. Suffixes can also be derivational as -less in hopeless. Based on all the explanation above, it can be understood that as the smallest part of language or sentence, morphemes have a very important function for understanding the classification of a word in a sentence, paragraph or discourse.

\section{RESEARCH METHOD}

Kothari (1990:31) stated that the arrangement of conditions to collected and analysis of the data in a manner the aims to combine relevance of the research purpose with economy in procedure is called research design. In fact, it is the conceptual structure within which research is conducted; it constitutes for the collection, measurement and analysis of data. In this study the writer used descriptive method to gain the data dealing with the derivational bound morpheme found in Magena language. Descriptive approach is a character description of the data that is done accurately based on data naturalistic.

Techniques of data collection to applied in this research observation, interview, recording, note taking and documentation study (Bungin,2007: 41). Based on the five kinds of instruments above, the writer used interview for getting the data, information, from the informants about the derivational bound morpheme of Magena language in central Sumba. Bodgan Sugiyono,(2012:41) states that data analysis is the process of systematically searching and arranging for the interviewed transcripts, field notes, than the other materials that accumulate to increase in own the writer understanding of them and to enable to present what have discovered to others. As for that, in order to get the natural data the writer provide some procedures and techniques to analyze the data. 1) Transcribe the recorded data. In this section the writer used the record of the story telling from folklore of the informants and takes note on the derivational bound morphemes. 2) Identified derivational bound morpheme from the data. To identify the morpheme the writer has to focus on derivational bound morpheme words. 3) Categorized and classified derivational bound morpheme from the data. 4) Analyzed the function of derivational bound morpheme from the folklore of the story telling.

\section{FINDINGS AND DISCUSSION}

After analyzing all data from informants, the writer would like to describe about the functions of derivational bound morphemes in Magena language based on the theory of Fromkin (2005:73). This theory stated that, every word consists of one or two or three, or more. A word may consist of free morpheme, bound morpheme, affixes, derivational morpheme, and inflectional morpheme.

\section{1) Free morpheme}

Magena language have free morphemes which consist of noun, verb, adverb, pronoun, adjectives, and determiner. All free morpheme can be attached by prefixes, Prefix that attach to noun :(na-)+ aru = na'aruna (his brother or her sister) Example : yida wuatuneka naaruna pajadu hangaju They are publication of the last brother for to become as a king. Prefix that attach to adverb :(na-) + lihu = nalihu (near)

Example : nalihu ummugu pahangang de (my neighbor are fingthing) Prefix (na-) is attach to adverb lihu means near.

Prefix that attach to adjectives are $:(m a-)+$ pengu = mapengu (clever) Example : mapengu naolugu (my friends are clever) (ma-) + manadangya = mamanadangya (verybeautiful)

Suffixes that attach to possessive :Inna $+(-g u)=$ innagu (my mother)

Example : nainnagu macurrune (my mother is sleep) Suffixes (-gu) is attach to possessive inna means mother.

Suffixes that attach to verb: 
Witu + (-ne) = witune (beat) Example : namahawurung witune matu

Suffixes that attach to adjective Manadangi + (-ya) = manadangiya (beautiful)

Example : naaragu mamanadangiya (my sister very beautiful) suffixes (-ya) is attach to adjective manadangi means beautiful.

\section{2) Bound morphemes}

There are some kinds of bound morpheme in Magena language that can be attached to noun, verb, pronoun, adverb, and adjectives. Bound in Magena language are: Na-has the function as prefix which refers to singular noun Example : (na-)+ inna = nainna (her mother ) $\mathrm{Pa}$ - as prefix has the function which changed the adverb become to verb Example: (pa-)+ diur = padiur (to turn) Da-as prefix has the function which changed the singular to plural noun.

Example : (da-)+ anuk = da'anuk (children) I-has the function as prefix which refer to third person singular Example :(l-)+ ittane = l'ittane (she is looking) Ne- has the function as prefix which passive of third person singular $\mathrm{Ya}$ - has the function as prefix which refer to third person singular. Gu- has the function prefix as passive first person singular.

The examples presented reveal that the bound morphemes in Magena language can be in the forms of prefixes, suffixes change the meaning if the attach to morpheme of words.

Example :. naumma kapatangne dada padiur maha na apu. (the dark not to turn the lamp)

Prefixes da in Magena language is always refers to the plural noun Example : Daanuk = means the children.

Based on the examples above the writer could say that prefix in Magena language can change the meaning of words if they attach to morpheme.

Example : . yida halakude lopa botung mapajolu bola (they are go to watching playing football).

This suffixes in Magena language always refers to pronoun. Example : suffixes -gu in word korunggu is refers to first person singular. Suffixes -ne in word macurrune is refer to third person singular. Suffixes - de in word halakude is refers to second person singular. Suffixes me in word in word botungme is refers to is refers to first person plural.

\section{3) Circumfixes}

Suffixes may also appear in multi in multi circumtanses.

Example :Dama paoludadung dama hamengu walung tana Babel

( the brothers to coming from in Babel ).

\section{4) Derivational morphemes in Magena language}

Derivational in Magena language can change meaning of words by creating new words. Derivational in magena language are : Hilu $=($ language $)+($ pa -$)=$ pahilu means speaking Ngidung $=($ bring $)+($ pa $)=$ pangidung means sendOlu $=($ friend $)+(p a)=$ pangolu means mixed.

Derivational morphemes in magena language are classified in two kinds they are :Derivational morphemes change part of speech Example : (pa-) + ngangu (eat) = pangangu (foods) (pa-) + ohung (collect) = paohung (collections) Derivational morphemes can be prefix and suffixes

Example :(pa-) + mangoma (marry) = pamangoma (to married)

$$
\text { (-na) + panewu (ask) = panewuna (ask them) }
$$

Based on the explanation above the writer would like to say that morphemes of Magena language for prefix and suffixes are have their own function.

\section{5) Inflectional morphemes in Magena language.}

The inflectional morphemes in Magena language are : Ngangu (stem) -ne (suffixes) third person singular (function) Example : yina ngangune uhu (she eat rice) Umma (stem) -gu (suffixes) = possessive Example : naummagu (my house). All inflectional morpheme in Magena language are suffixes only, they are : dawoluihu $+(-n a)=$ dawoluihuna (body hair) Wapa $+($ ne) =wapane (capture) Based on the explanation previously the writer would like to say that affixation process in Magena language can happen based on the subject. 


\section{CONCLUSION AND SUGGESTIONS}

Based on the result of the data analysis, the writer can conclude that the results of the study shows that there are many derivational bound morphemes in Magena language. Derivational bound morpheme that the writer got from the data available are free morphemes, bound morphemes, affixes derivational, circumfixes, and inflectional morphemes. Free morphemes in Magena language consist of one syllable like : tahuk (sea). Two syllable like : penguya $(-\mathbf{y a})=$. Three syllable like $:$ naaruda $($ na-) + aru $-\mathbf{d a}=$ naaruda (they brother ). Bound morpheme in Magena language is also consist of affixes, derivational morphemes and inflectional morphemes,. Affixes consist of prefixes, suffixes and circumfixes example : (pa-) + ngangu = pangangu (foods), (da-) + anuk =daanuk (children), (da-) + boku = daboku (grand father), (I-) amma = I amma (father).

In Magena language prefix which attach to every class of word is different. Prefix naand $\mathbf{I}$ - is only attach to noun singular. Prefix da- only attach to verb. Suffixes in Magen language are : -ne,-da, -gi, -na. -gu. -ya. Example : lo $+(-n e)=$ lone (going), pukal $+(-\mathbf{g i})=$ pukalgi (I free), aru + (-da) = aruna (her sister), tana $+(-\mathbf{g u})=$ tanagu (my land), gailar $+(-\mathbf{y a})$ = galangya (very large). Circumfixes in Magena language always change the meaning of word. Example : (pa-) + ohung $(-\mathbf{g i})=$ paohunggi (I am collection ). ohung is verb means collection. But in circumfixes form it become verb. Derivational morphemes in Magena language the change part of speech like : (dana-) + pahama = danapahama (not same). Derivational In prefix like: paohung means collections (verb), pangangu means foods (noun), and naanada means children (noun). Derivational morphemes in suffixes form like : pakayu means buy (verb), halakune means walks (verb). Inflectional morphemes in Magena language are suffixes and possessive suffixes like : lo $+(-n e)=$ lone (his going), and suffixes as possessive is tana $+(-\mathbf{g u})=\operatorname{tanah}$ (my land). Functions derivational bound morphemes in Magena language are: prefix - pa is to change the class of words change noun become to verb. $\mathrm{Na}$ - the function of prefix na- is refers to singular noun. Prefix da- the function is refers to plural noun.Suffixes are -ne,-gu,-me, and ya.

The function of suffix - ne as possessive of first person singular. The function of suffix ne as possessive of first person singular. The function of suffix -me as possessive of first person plural. The function of suffix -ya refers to third person singular as adverb. Circumfixes are pa-,and -gi prefix pa- and suffix - gi has the function to change the part of speech. Derivational morpheme is pa-+ = pahilu prefix pa- change the meaning hilu (language) become pahilu (speaking). The last is inflectional morpheme. Inflectional, are -ne which refer to third person singular and -gu which refer to possessive of person singular.

Based on the explanation above it can be concluded that the bound morphemes which consist of affixes, derivational and inflectional morpheme have their own function in use. The derivational morphemes and inflectional morphemes also existing in this language but not all derivational and inflectional rules in English occur in this language.

Based on the result of data analysis, the writer provides some suggestions as follows: It is advisable for the native speaker in Magena language to preserve their local language and to keep using the language in daily life. Magena language is a $n$ interesting language and worth for further study.

\section{REFERENCES}

Akmajian, A. \& Heny, F. (1975) An Introduction to the Principles of Transformational Syntax, MIT Press, Cambridge Mass

Arikunto, B.1996. Prosedur Penelitian. Jakarta: Rineka Cipta.

Botha, Rudi P. 1988. Form and Meaning in Word Formation: A Study of Afrikaans Reduplication. Cambridge: Cambridge University Press.

Bungin, B. 2007. Penelitian Kualitatif: Komunikasi, Kebijakan Publik, dan IImu Sosial Lainnya. Jakarta: Prenada Media Group.

BPS -Statistics of Sumba Barat Regency. 2009. Sumba Tengah in figure. Percetakan CV. Aneka surya.

Djajasudarma, Fatimah. 1993. Metode Linguistik. Bandung: Eresco. 
Djoko, Koenthono. 1984. Dasar-Dasar Linguistik Umum. Jakarta: Fakultas Sastra Universitas Indonesia.

Fromklin, Victoria. Et.al (2005). An introduction to language

Geert Booij, 2007 The Grammar of Words An Introduction to Linguistic

Morphology Second edition

Haspelmath, M. (2002) understanding morphology. London: Arnold

Healey, Phyllis M. 1960. An Agta grammar. Manila: The Institute of National Language and The Summer Institute of Linguistics.

Jacob J. 2006. morphology hand out

Kosi et al. 2010. Hutan dan Burung di Pulau Sumba. Kurikulum Muatan Lokal Sumba Tengah. Burung Indonesia

Kothari, R. C. 2004. Research methodology method and Techniques. New Delhi.

New Age international publishers. (second revised edition)

Ngongo, M. 2013 An introduction to educational research method. An instructional material. FKIP UKAW- Kupang. (unpublished Handout)

Nida, E. 1949. The Descriptive Analysis of Word (Second Edition) Oxford. University Press New York.

O'Grady, O. W. and V. P. de Guzman. 1996. Morphology: The Analysis of Word Structure. UK: Addison Longman Limited.

Sabaora P. Andereas. 2009. Buku muatan lokal, pendidikan lingkungan sosial

Budaya (PLSB) Daerah sumba Tengah. First edition. SDM Waibakul. 